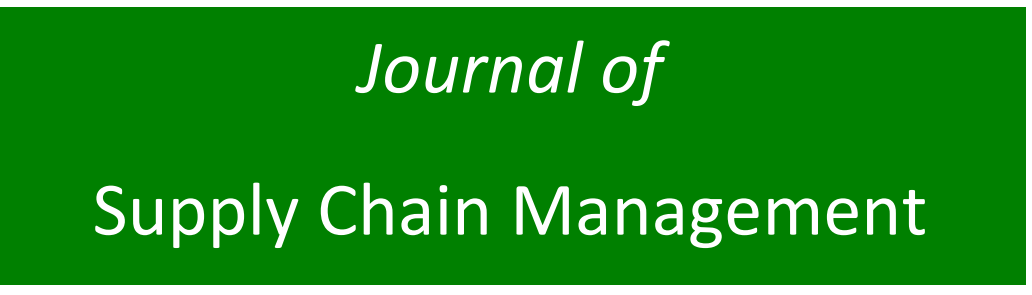

\title{
The Impact of Supplier Sustainability Risk on Shareholder Value
}

\author{
Seongtae Kim, Stephan M. Wagner, \& Claudia Colicchia
}

This is the peer reviewed version of: Seongtae Kim, Stephan M. Wagner, \& Claudia Colicchia (2019), “The Impact of Supplier Sustainability Risk on Shareholder Value”, Journal of Supply Chain Management, Vol. 55, Issue 1, which has been published in final form at https:// doi.org/10.1111/jscm.12188. This article may be used for non-commercial purposes in accordance with Wiley Terms and Conditions for Use of Self-Archived Versions.

\begin{abstract}
Business scandals like sweatshop labor have received growing attention in the field of supply management. Yet little is known about how detrimental such scandals are to buying firms. This study aims to fill this gap by examining the magnitude of the consequences of what are termed supplier sustainability risks (SSRs). To this end, we conduct an event study analysis followed by regression modeling based on a sample of 196 US publicly traded firms' SSRs. The results reveal that SSRs are associated with a $1.00 \%$ reduction in shareholder wealth. The market reacts negatively but not differently to the two types of SSR: process-related risks and product-related risks. Finally, a firm's moral capital does play a mitigating role for SSRs and process-related risks; however, it does not provide insurance-like protection for product-related risks.
\end{abstract}

Keywords: Supplier sustainability risk, Social performance, Corporate social responsibility, Insurance-like value, Shareholder wealth 


\section{INTRODUCTION}

On the night of Saturday, 27 November 2012, a fire broke out at the eight-story Tazreen factory on the outskirts of Dhaka, Bangladesh, killing at least 117 garment workers. Less than a year later, another eight-story building, the Rana Plaza, collapsed near Dhaka, causing 1,129 fatalities and more than 2,500 injuries (Guo, Lee \& Swinney, 2016). Placing the blame where it belongs is debatable. However, soon after both incidents, many western clothing retailers, such as WalMart and Gap, were found to be involved, and these multinational firms were accused of having little regard for safety conditions (Jacobs \& Singhal, 2017). The question still remains: how detrimental are such supplier scandals to buying firms?

It goes without saying that such scandals can have negative consequences for the buying firms; but most of the evidence we have seen is anecdotal (e.g., Foerstl et al., 2010; Hofmann et al., 2014; Reuter et al. 2010). Indeed, much less is known about the magnitude and severity of the consequences. In fact, few studies have presented rigorous evidence. However, one study is limited to a single event (Jacobs \& Singhal, 2017), while others focus only on boycotts or other outcomes of incidents (Bartley \& Child, 2011; King \& Soule, 2007). More importantly, events like the Tazreen factory fire and the Rana Plaza disaster were often associated with suppliers’ unethical behavior; none of these studies address supplier sustainability (responsibility) from a risk perspective.

This study aims to fill this gap by examining the magnitude of the financial consequences of what are termed supplier sustainability risks (SSRs). SSRs are the damaging effects that a buying firm has to bear when news of its suppliers' ethical/moral misconduct become public (Chen \& Lee, 2017). This emerging concept was elaborated by Foerstl et al. (2010); since then, there have been many scholarly efforts to distinguish SSRs from supply disruption risks (SDRs) (e.g., Busse, Kach \& Bode, 2016; Giannakis \& Papadopoulos, 2016; Hajmohammad \& Vachon, 2016). SSRs occur when buying firms are caught doing something that may trigger adverse stakeholder reactions (Barnett, 2014; Hofmann et al., 2014); SDRs normally arise from operational failures (e.g., delay) or natural/manmade disasters (e.g., a factory fire) (Kleindorfer \& Saad, 2005). 
SSRs are part of the wider concept of sustainability risk, which is not limited to ecological issues but also social matters in supply chains. This concept builds on the triple bottom line view of sustainability, emphasizing the combination of people (i.e., social), planet (i.e., environmental) and profit (i.e., economic) for continuous development (Elkington, 1997). In fact, sustainability research in the field of operations and supply chain management (OSCM) has traditionally focused on the planet. However, this one-sided focus makes it difficult to examine the aggregated impact of sustainability issues on a firm's performance (Shafiq et al., 2014). Indeed, Klassen and Vereecke (2012) asserted that social issues in supply chains lag far behind, making firms struggle with an understanding of their causes and effects. For this reason, we focus on the people-side of sustainability risks under the name of SSRs.

In this study, we adopt the concept of stakeholder reaction and efficient market hypothesis to explain how SSRs can be punished by the capital market. In particular, we consider stakeholder salience, a stakeholder whose attributes might be strong enough to sustain actions against SSRs, thereby shaping stock market behavior. Social issues in supply chains can be defined as "product- or process-related aspects of operations that affect human safety, welfare and community development” (Klassen \& Vereecke, 2012, p. 103). Building on this definition, we examine whether there are differential effects between the types of SSR. Finally, managers can protect themselves against SSRs by obtaining and maintaining moral capital from stakeholders (Godfrey, 2005). We thus introduce the buffering effect of corporate social responsibility (CSR), and test if this effect could play a mitigating role during SSRs.

This paper contributes to research and practice in the following manner. First, it increases our knowledge about how detrimental SSRs are to buying firms. Beyond the anecdotal evidence (e.g., Foerstl et al., 2010) more research is needed to investigate the magnitude of the SSR. Second, this study advances the understanding of CSR as insurance during SSRs. This idea is designed to reduce the potential damage to a firm's reputation, something which has yet to be addressed in the literature. Third, this study balances the social aspects of sustainability research, where most prior studies have focused on environmental issues (Kim, Colicchia \& Menachof, 2016). This study reviews SSR-related studies based on the process/product distinction to arrive at deeper insights into the literature. 


\section{SUPPLIER SUSTAINABILITY: A RISK PERSPECTIVE}

\section{Concept of SSR}

Supply chain scholars have been concerned with typical, ordinary risks (e.g., parts delays or shortages) that often trigger disruptions (Kleindorfer \& Saad, 2005). A supply chain disruption can be defined as the combination of “(1) an unintended, anomalous triggering event that materializes somewhere in the supply chain or its environment, and (2) a consequential situation which significantly threatens normal business operations of the firms in the supply chain” (Wagner \& Bode, 2008, p. 309). There have been many typologies/taxonomies of disruption risks; however, for our purposes, this study compares SSRs with "pure" issues that occur in the upstream side of supply chains, and thus SDRs (Harland, Brenchley \& Walker, 2003; Wagner \& Bode, 2008; Zsidisin et al., 2004).

In contrast to SDRs, a SSR builds on the concept of sustainability risks, defined as "a condition or a potentially occurring event that may provoke harmful stakeholder reactions” (Hofmann et al., 2014, p. 168). In fact, as pointed out by Foerstl et al. (2010, p. 119), SSRs “are generally not, or at least not in their entire content breadth, part of the supply risk management discussion.” However, this concept has recently attracted much attention, given that SSRs can compensate for the limitations of SDR management (Busse et al., 2016; Foerstl et al., 2010; Reuter et al., 2010). To illustrate this point: today's multinational firms enjoy a renowned ability to govern their global supply chains for SDRs. Nevertheless, plenty of evidence still shows the limited effect when a buying firm encounters negative developments like SSRs (e.g., Apple-Foxconn's suicide scandals).

Consequently, SSRs "lie at the intersection of sustainable supply chain management and research on global supply chain risks” (Busse et al., 2016, p. 313). In this regard, it is inevitable that SSRs may overlap with SDRs. As an example, consider the Rana Plaza case. Jacobs and Singhal (2017) argued that global apparel retailers sourcing from Rana Plaza may face not only damage to their reputation, but also supply disruption. Therefore, while concentrating mainly on SSR- 
only event, this study also considers such overlapping issues. In robustness checks, yet, we will show if our results are driven by these kinds of SSRs.

Two conditions are essential for harmful stakeholder reactions to occur and thus for SSRs to materialize (Barnett, 2014; Hofmann et al., 2014). First, stakeholders should notice a firm that engages in the problematic issues caused by suppliers' ethical/moral misconduct (noticing). Second, the stakeholders should judge the situation as undesirable and hold the buying firm accountable (assessing). Thus, it is important to note that the extent of damage may depend on situational factors. For example, when the Rana Plaza collapsed, this tragedy hit the headlines of every newspaper. However, despite extensive media coverage, the western retailers linked to Rana Plaza did experience only a limited market penalty from the disaster (Jacobs \& Singhal, 2017). In contrast, no matter the reason, SDRs devastate corporate value (Hendricks \& Singhal, 2003, 2005).

\section{Types of SSR}

Process-related risks. Risk sources that could trigger SSRs are often associated with worker rights. Some of them include sweatshop conditions, unfair wages, child/forced labor, and discrimination, all of which are issues that stakeholders might view as socially undesirable. The risk sources of SSR are also associated with safety concerns at workplace such as the Tazreen factory fire and the Rana Plaza disaster. Consequently, these SSR issues are consistent with two different but conceptually interrelated streams of research in the field: sweatshop labor and workplace safety.

Sweatshop labor is the term often used to describe oppressive working conditions. The term is often synonymous with “modern slavery” (Gold, Trautrims \& Trodd, 2015; New, 2015), which is more pervasive but has received less attention in the OSCM literature. This negligence applies also to workplace safety, better known as occupational health and safety (OHS) (Lo et al., 2014). Workplace safety relates to sweatshop labor - Apple-Foxconn's labor abuses that hurt workers are just one example (see Chan, 2013). Indeed, many stakeholder groups now demand workplace 
safety as a basic human right (Lo et al., 2014). In this study, we use both terms as an interrelated concept, under the name of SSR.

For our purposes, and following prior studies (e.g., Kach et al., 2016; Klassen \& Vereecke, 2012; Wagner \& Bode, 2014), we labeled these issues as process-related risks (see Table 1). As a type of SSRs, process risks arise from suppliers’ ethical/moral violations of worker's rights. Chen and Lee (2017) argued that this kind of risk can be detected through process audits and/or inspections (e.g., Apple’s factory/process inspection in China, see Sherr, 2011). This topic is often examined by social scientists (e.g., Bartley \& Child, 2011); yet, as noted earlier, they are limited to outcomes (e.g., boycotts). In this study, following the definition of sustainability risk (Hofmann et al., 2014), we focus on conditions of the incident, and examine process-related issues from the SSR perspective.

Insert Table 1 about here

Product-related risks. Besides the process-related issues, SSRs are associated with productrelated concerns, also known as “product-harm crises” (Chen, Ganesan \& Liu, 2009). In summer 2007, for example, the American toy manufacturer, Mattel, announced a recall of nearly one million lead-tainted toys manufactured by Chinese suppliers (Casey, 2007). In 2012, the fast food giant, Yum, was criticized for the improper use of antibiotics in chickens supplied by food manufacturers in China (Murphy, 2012). Consequently, such SSRs are associated with a stream of research on product quality and safety issues, an emerging topic in SDR research (Marucheck et al., 2011; Speier et al., 2011).

In the literature, quality risk refers to the likelihood that a product shipped from the supplier side will not function as intended (Gray, Roth \& Leiblein, 2011). Similarly, risk related to product safety refers to the likelihood that use of the product will harm its users (Marucheck et al., 2011). Both quality and safety issues are thus associated with product recalls, a topic that has received less scholarly attention in the field of OSCM (Wowak \& Boone, 2015). Quality management (QM) research has focused on it (e.g., Gray et al., 2011). However, as noted by Steven, Dong \& 
Corsi (2014), there is a dearth of QM studies in a supply chain context. This lack of research is especially the case for quality and safety issues from an SSR (i.e., sustainability) point of view.

For our purpose, building on prior studies (e.g., Klassen \& Vereecke, 2012), we labeled these issues as product-related risks (see Table 1). From an SSR point of view, product related-risks arise from suppliers' ethical/moral misconduct in undermining product quality/safety. Chen and Lee (2017) argued that this kind of risk can be discovered by product audits and/or inspections (e.g., retailers' product audits, see McQueen, 2007). Compared with process-related issues, this topic seems to have received slightly more attention (e.g., Ni, Flynn \& Jacobs, 2014; Zhao, Li \& Flynn, 2013) in OSCM research, but from a typical (pure) risk perspective. In contrast, in this study, we focus on product quality and safety issues resulting from unethical supplier behavior (e.g., intentional acts).

\section{THEORY AND HYPOTHESES}

\section{Stakeholder Reaction}

A stakeholder can be defined as "any group or individual that can affect or be affected by the realization of an organization's purpose” (Freeman et al., 2010, p. 26). Since the mid-1980s, various types of stakeholders have been discussed, given the assumption that a firm never satisfies every stakeholder’s demands (Kim \& Lee, 2012). Mitchell, Agle and Wood (1997) classified stakeholders based on the absence or presence of unique attributes: power (i.e., the ability to effect the desired outcomes), legitimacy (i.e., a generalized perception that actions of an entity are desirable) and/or urgency (i.e., the degree to which claims call for immediate attention). Simply, stakeholders who possess all three of these attributes should receive the most attention from a target firm.

This concept of stakeholder salience is useful for this study as it relates to SSR (Hajmohammad \& Vachon, 2016). Following prior studies (e.g., Freeman et al., 2010), we provide a partial list of stakeholders who are active in SSRs: consumers, regulators, communities, (local) employees, non-government organizations (NGOs), and the media. We refer to the first three as "direct" and 
the last three as "indirect" (Frooman, 1999). Employees are often regarded as stakeholders with direct influence (Hofmann et al., 2014). In this study, however, we limit ourselves to employees in the context of a supplier, whose claims thus have an indirect effect. We also note that the media and NGOs may act on behalf of the less influential stakeholders, whose activities can mobilize public opinion against the SSR (Kim \& Lee, 2012). In this sense, stakeholders combine forces to elicit positive responses from the target firms.

It should be also noted that in this study, we focus on investor behavior toward stakeholders' reactions against firms' SSR. Investors are also stakeholders, who are likely to be affected by other "stakeholders' reactions to a critical event", and thus have "strong incentives to use all information available to assess the likelihood" of the occurrence of SSRs (Dorobantu, Henisz \& Nartey, 2017, p. 568). Thus, when news media report supplier misconduct, investors evaluate the scandal by inferring if the supplier's social irresponsibility pushes stakeholders to take action, and if such reactions can present risks (e.g., deceased sales) to the target firm. In what follows, we describe how investors respond to stakeholders' reaction to SSRs, and how this reaction can depend on the type of SSR.

\section{Stock Market Behavior}

This study builds on the efficient markets hypothesis, suggesting that the stock price of a firm reflects all currently available public information, and, in turn, the collective perceptions of investors regarding the firm's future cash flows (Fama, 1970). Under this view, "an event is anything that results in new relevant information” (McWilliams \& Siegel, 1997, p. 630).

Therefore, significant events like SSRs can be assessed by observing stock price behavior over a certain period of time, known as "event window". This aspect provides a basis for the method used in this study, which we will discuss in more detail later. A large body of work supports the hypothesis that markets are efficient (Fama, 1970), although this view is still the subject of debate (see Mishkin, 2012).

We argue that SSRs can cause a shareholder value loss of the buying firm in the following mechanisms. First, SSR-related issues, when publicized by the media (or NGOs), are likely to 
reinforce negative images of the firm (Mitchell et al., 1997; Roehrich, Grosvold \& Hoejmose, 2014). Second, the tarnished firm image with unacceptable SSR-related issues may provoke adverse reactions from (salient) stakeholders (Barnett, 2014; Busse et al., 2016; Hofmann et al., 2014). Third, investors modify their expectations that the firm could lose its tangible (e.g., cash) and intangible (e.g., reputation) assets from the SSR (Cordeiro \& Tewari, 2015; Gilley et al., 2000). Fourth, investors' perception is reflected immediately in the adjustment of stock prices (Fama, 1970).

The change in stock prices that results from announced SSRs presumably reflects the investor's perception of its potential effect. Therefore, if investors view SSR-related events as potentially problematic, they are likely to interpret such risks as a signal of current and future damage to the buying firm. Taking a typical risk perspective, Jacobs and Singhal (2017) asserted that the Rana Plaza disaster is likely to imperil the reputation of western retailers, causing negative reactions from investors. In a similar vein, Thirumalai and Sinha (2011) argued that medical recalls resulting from product-harm crises diminish the overall credibility of the target firm, which will be reflected in a downward adjustment of stock prices. Given the foregoing discussion, we posit the following hypothesis:

H1: The stock market will react negatively to the announcement of SSRs.

In this study, we argue that compared to product-related risks, the shareholder value effect of process-related ones may be lower. The rationale is as follows. Process risks are business scandals, in which the affected parties tend to be local employees. As indirect influencers, their claims might be legitimate and urgent but not powerful (Busse et al., 2016; Mitchell et al., 1997). Such an absence of the power attribute would make the local employees difficult to sustain actions against the process events. In contrast, the shareholder value effect of product-related risks may be greater. This is because, unlike process events, issues related to product affect the well-being of more salient stakeholders, especially consumers. For example, product safety issues tend to affect consumers' health; Mattel's case is critical because its products are intended for children (Hora, Bapuji \& Roth, 2011). 
Taken together, process risks are distant, while product risks are closer to stakeholders who can directly retaliate against the buying firm. Plus, because of the absence of attributes (legitimacy and urgency, but not power), local employees are less likely to elicit a positive response from the firm to their requests (i.e., moderate salience). In contrast, consumers are more salient, whose attributes can elicit active responses from the buying firm (i.e., high salience). Such a difference may send different signals to the investment community. That is, compared to process events, investors may view product issues as more problematic in maintaining the firm's value, and thus assign more weight to those kinds of SSRs. Given the discussion, we posit the following hypothesis:

H2: The stock market will react more negatively to the announcement of product-related risks than of process-related risks.

\section{Insurance-like Protection}

CSR is known to “differentiate a firm's products, reduce its operating costs, and serve as a platform for future opportunities, as well as a buffer from disruptive events” (Barnett, 2007, p. 796). Among these benefits, this study focuses on the buffering effect of CSR, known as insurance-like protection (or reputation insurance) (Minor \& Morgan, 2011; Peloza, 2006). The premise of this emerging theory is that a firm's CSR performance acts as insurance (buffer) during a negative event like SSRs, as protecting the firm’s reputation by mitigating harmful reactions from stakeholders.

Godfrey (2005) was the first to elaborate on this view. Relying on multiple bodies of literature, the author made the following assertions regarding its mechanism: first, social performance generates positive moral capital among stakeholders; second, the moral capital, which is the outcome of the process of assessment by stakeholders of a firm's CSR activities, can protect a firm's relationship-based intangible assets; and finally, this insurance-like protection contributes to shareholder value (Godfrey, 2005).

This study posits that social (CSR) performance can act as a firm's approach for mitigating the magnitude of SSRs. As stated earlier, unlike SDRs, a firm’s SSRs normally arise from harmful 
stakeholder reactions caused by suppliers' unsustainable behavior. We argue that a high level of social performance (moral capital) may protect the image of an affected firm, thereby mitigating the potential negative reactions from stakeholders against SSRs. This may send an important positive signal to investors' perceptions about the firm's current and future prospects, which will then be incorporated into stock prices.

Several studies provide empirical evidence on this aspect, albeit not from a SSR management point of view. For example, Godfrey, Merrill and Hansen, (2009) revealed that when a firm engages in CSR, shareholder wealth declines significantly less following a negative event (e.g., patent infringements). Similarly, Flammer (2013) also found that firms engaging in CSR can benefit from insurance-like protections during the occurrences of eco-harmful events. The evidence is further supported by recent studies by Koh, Qian and Wang (2014) and Shiu and Yang (2017), both of which have revealed the insurance effect of CSR. Therefore, we posit the following hypothesis:

H3: A firm's social performance will attenuate the market's negative reaction to the announcement of SSRs.

It should be noted, however, that the insurance effect does not always occur at the same level. The effect can vary depending on the nature of the event - the more ambiguous the signals about a buying firm's moral values, the greater the insurance effect (Godfrey, 2005). The ambiguity often arises where ethical/social norms are contested between the firm and its suppliers. In this study, process-related risks can fall under this category as they are affected by institutional factors that normally differ much among players in global supply chains. For example, regulators in the context of a buyer may act on behalf of affected local employees, punishing the buying firm (Busse et al., 2016). Yet, its institutional difference may leave open the possibility of weakening the causal linkage, as the firm could attribute the cause of the risks to their suppliers (Jacobs \& Singhal, 2017).

In contrast, ethical/social norms of product-related issues do not vary widely, because it is generally understood that the resulting crises are likely to become serious problems for 
stakeholders of both the buyer and supplier (Hora et al., 2011; Ni et al., 2014; Roth et al., 2008). This sends a clearer signal of a buying firm's behavior, so the moral assessments of the productrelated scandals can be made more clearly by relevant stakeholders. This is especially the case when considering that the affected stakeholders, particularly consumers, can directly blame the target firm for the unpleasant event. Therefore, the veracity of evidence for product-related risks might be less ambiguous when compared to that of process-related risks. Given this context, we posit the following hypothesis:

H4: A firm's social performance will attenuate the market's negative reaction to the announcement of process-related risks more than of product-related risks.

\section{RESEARCH DESIGN}

\section{Sample of SSRs}

To generate our sample, we searched news articles about SSRs in the Wall Street Journal (WSJ) from 1985 to 2014. We chose the WSJ because it is the largest business newspaper in the US, and plays a major role in shaping investors’ behavior (e.g., Godfrey et al., 2009). The keywords used in the search include combinations of the following SSR-related words: supplier, contractor, sourcing, ethic ${ }^{*}$, social ${ }^{*}$, responsib* , sweatshop, labor, worker, rights, child, workplace, abuse, health, safety, violation, overtime, explosion, collapse, fire, product, food, and other relevant terms. We read the full text of articles and downloaded those that were related to SSR events (367 articles spanning 655 firms’ SSRs).

For an SSR-related event to be included in our final sample, it had to meet the following criteria:

- $\quad$ The sample firms must be publicly traded on US (New York, American, or Nasdaq) exchanges, and have sufficient stock price information for the estimation period. Based on this criterion, 367 events were eliminated.

- The SSRs must arise from a "condition” that might trigger harmful stakeholder reactions (Hofmann et al., 2014). We therefore eliminated 74 events that were associated with outcomes of the condition, such as boycotts and labor strikes. 
- The SSR must be isolated from the effects of other financially relevant events such as mergers. To ensure this, we isolated 18 confounding cases by checking all WSJ announcements for each sample firm during the two-day event window (McWilliams \& Siegel, 1997).

Our final sample consists of 196 US publicly traded firms’ SSRs collected from 156 announcements (available upon request). Examples include "Foxconn factory in China used 14year-old workers" (October 17, 2012) and "Mattel toys to be pulled amid lead fears" (August 2, 2007). The former case is a process-related SSR, in which underage workers were employed by Foxconn, a major Apple supplier. The latter case is a product-related SSR, in which Mattel recalled Chinese-made toys that contained dangerous amounts of cheap and readily available lead. Our sample meets the criteria, and as the examples show, they are associated with suppliers' ethical/moral misconduct.

Many SSR events received continuous news coverage. Unlike SDRs, which often occur entirely by chance, this might be expected given that the veracity of evidence is ambiguous. This is especially likely when questions of ethical and/or moral issues are involved, like SSRs. In this study, we ignored such follow-up news articles, unless they convey relevant new information (e.g., another suicide at the Apple's supplier plant) that might update investor's beliefs about the target firm's behavior (Flammer, 2013; Dorobantu et al., 2017). Therefore, we eliminated news articles that simply update a previously reported SSR from our data set. Yet, we will show in robustness checks that our results are not driven by those 'subsequent' events (see "subsequent coverage” in Table 5).

Insert Table 2 about here

Table 2 presents the sample distribution. We grouped our sample into three time periods. More than 70\% of the sample firms were caught engaging in SSRs between 2005 and 2014. This is in line with the global sourcing trend that gives the advantage of lower production costs but is also subject to suppliers' misconduct (Chen \& Lee, 2017). Sample firms were also grouped into five industry types, based on two-digit standard industrial classification (SIC) codes. Manufacturing 
(63.8\%) was the most frequently occurring SIC code (SIC 20-39), where many were from "petroleum and coal products" (SIC 29). This was followed by wholesale \& retail trade (30.6\%) (SIC 50-59), where most were from "general merchandise stores" (SIC 53).

\section{Analytical Techniques}

Event Study. To test H1 and H2, this study uses an event study. The event study is based on the assumption that given efficient market theory, the magnitude of abnormal returns (ARs) at the time of an event provides a rigorous measure of shareholder wealth (MacKinlay, 1997). In this sense, event study is often regarded as a powerful method for the assessment of the financial impact of a firm's certain behavior (McWilliams \& Siegel, 1997), which this study applies in the context of SSR.

The stock market reaction to SSR events is captured by ARs (Brown \& Warner, 1985). To measure ARs, we use the market model on daily stock price data. The market model is known as "the best specified model” (Hendricks \& Singhal, 2003), and estimated:

$$
R_{i t}=\alpha_{i}+\beta_{i} R_{m t}+\varepsilon_{i t},
$$

where $R_{i t}$ is the return on the stock of firm $i$ on day $t, R_{m t}$ is the return of the market index (S\&P 500 ) on day $t, \alpha_{i}$ is the intercept term, $\beta_{i}$ is the systematic risk of stock $i$, and $\varepsilon_{i t}$ is the error term. The AR of firm $i$ on day $t$ is then calculated from the market model:

$$
A R_{i t}=R_{i t}-\left(\hat{\alpha}_{i}+\hat{\beta}_{i} R_{m t}\right),
$$

where the firm-specific factors, $\hat{\alpha}_{i}$ and $\hat{\beta}_{i}$, are estimated using ordinary least square regression over an estimation period of 200 trading days (i.e., -210 to -11 ).

The AR for day $t$ can be aggregated over all $N$ events:

$$
\overline{A R}_{t}=\frac{1}{N} \sum_{i=1}^{N} A R_{i t}
$$


where $N$ is all events in our sample. Finally, the cumulative abnormal return (CAR) for $\left[t_{1}, t_{2}\right]$ is then computed by summing up the ARs over the days in the event window:

$$
C A R\left[t_{1}, t_{2}\right]=\sum_{t=t_{1}}^{t_{2}} \overline{A R}_{t}
$$

where $t_{1}$ and $t_{2}$ represent the first and last day of the time window. Negative CARs will occur if the expected stock price is greater than the actual stock price change.

In this study, to better control for confounding effects, or estimation bias (McWilliams \& Siegel, 1997), we use the shortest possible window. Simply, it is achieved by setting the announcement date as the event window (i.e., day 0). Yet, this approach can be problematic, as we use data from print media, and thus the market could have been informed about the SSR a day earlier (i.e., day -1) (MacKinlay, 1997). For this reason, we expand the event window to two days (i.e., day -1 and day 0 ), which is common practice in the OSCM literature (e.g., Hendricks \& Singhal, 2003).

Regression Specification. Next, to test H3 and H4, this study regresses the two-day CAR [-1, 0] on social performance, controlling for the impact of other variables. Specifically, we estimate the following regression model:

$$
\text { CAR }_{i}=\alpha+\beta * \text { Social Performance } i+\gamma * X_{i}+\varepsilon_{i}
$$

where $C A R_{i}$ is the cumulative abnormal return for firm $i$ in the two-day event window, Social Performance $_{i}$ is the predictor variable, $X_{i}$ is a vector of industry-, firm-, and event-level control variables, and $\varepsilon_{i}$ is the error term. We also analyze the regression model separately for each of the SSRs, namely process- and product-related risks.

To measure a firm's social performance, we used cumulative CSR data provided by Kinder, Lydenberg and Domini (KLD). The KLD has provided environmental, social and governance performance data, which is a widely used measure of CSR. In this study, we rely on the 55 indicators of five social dimensions: community, diversity, employee relations, human rights, 
and product (Chen \& Delmas, 2011). Each indicator is measured as binary variables of positive (strength) and negative (concern) ratings, with a score of 1 if a firm meets positive or negative criteria and 0 otherwise (see KLD, 2010).

In this study, social performance is measured using KLD ratings based on the difference between the strength and concern indicators. One commonly used measurement is an aggregate of dimension scores; yet, this approach can be problematic because there is a lack of comparability; each dimension across the years (from 1991) has a different number of strength and concern indicators. We therefore follow Deng, Kang and Low (2013) and use the adjusted KLD ratings as:

$$
\text { Social Performance }_{i}=\frac{1}{N_{i}} \sum_{S=1}^{N_{i}} \text { strength }_{i s}-\frac{1}{N_{i}} \sum_{c=1}^{N_{i}} \text { concern }_{i c}
$$

where $N_{i}$ is the total number of strength and concern indicators for each dimension $i$, strength $h_{i s}$ is the positive indicator for criteria $s$, concern $_{i c}$ is the negative indicator for criteria $c$. Then, the adjusted social performance score can be computed by taking the average of the five social dimensions. We lagged this score by one year to control for the possibility that the KLD rating might be affected by the SSR event. The data were only available since 1991, so we reduced our sample to 126 for regression analysis.

In addition to the hypothesized variable, we included a number of controls in the regression model, as the SSR can be affected by factors such as industry type, firm size, time trend, supplier location, or event severity (Hajmohammad \& Vachon, 2016; Hora et al., 2011; Roehrich et al., 2014). For industry-level controls, we used a set of dummy variables to identify each industry type at the two-digit SIC level. As a firm-level control, we included firm size (the natural logarithm of total assets), as obtained from Compustat. Lastly, we included linear time trend (i.e., 1985, 1986...2014), and the three binary variables fatality, legal action, and emerging country as event-level controls. Table 3 shows the means, standard deviations, and correlations for all the variables used in this study.

Insert Table 3 about here 


\section{RESULTS}

\section{Event Study Results}

Table 4 presents the analysis result, examining stock market reactions to SSRs. We found that the mean CAR over the two-day event period $[-1,0]$ is $-1.00 \%$, which is significant at the $0.1 \%$ level. The median CAR for the event period is also negative $(-0.66 \%)$ and statistically significant. This evidence shows that the market reacts negatively to firms that are caught in SSRs, and thus provides strong support for H1 (negative market reactions to SSRs). Table 4 also shows that most SSR activity happens within the event window, supporting our two-day specification.

Insert Table 4 about here

Insert Table 5 about here

To ensure the robustness of our results, we conduct a series of checks. First, some SSRs involve a number of buyers per event, as these firms do business with one particular supplier. One concern could be that these "collective events" may complicate the inference of significance. We thus exclude these samples $(n=53)$ and re-estimate the mean (median) CAR. Next, in our sample, BP $(n=25)$ and Walmart $(n=18)$ were implicated in numerous SSRs. One may argue that our results can be driven by these dominant sample firms. To verify this, we re-estimate the mean (median) CAR, excluding these “abnormal samples.” We also re-estimate the mean (median) CAR using alternative (mean-, market-, and size/value-adjusted) models (for details, see Brown \& Warner, 1985; Fama \& French, 1993). As shown in Table 5, the results are very similar to those reported in Table 4.

As noted earlier, SSRs can receive constant attention from the public, mainly because of their association with moral/ethical issues. One might argue that such following events can dilute the 
true impact of SSRs. To verify this, we re-estimate the mean (median) CAR, without the "subsequent coverage." As Table 5 shows, this reduced shareholder value by $1.10 \%$ (0.80\%), which is very similar to before. We also performed a robustness check of "overlapping cases." To verify such cases, we rely on the content of the announcement. Thus, if the SSR news article also reports SDR-related words, such as "shut," "closed," "delays," "suspended,” we considered them as overlapping. We found only 10 such cases; but as shown in Table 5, our results are robust to these kinds of events.

Insert Table 6 about here

Next, to test H2, we estimated the differential effects of process-related versus product-related events by comparing their magnitude. As shown in Table 6, process-related risks are significantly associated with a mean (median) CAR of $-0.93 \%$ ( $-0.64 \%)$, while product-related risks have a mean (median) CAR of $-1.14 \%(-0.68 \%)$. However, it was revealed that the difference in the mean (median) CARs of the two types of SSR events is statistically insignificant. This evidence does reject $\mathrm{H} 2$ (greater negative market reactions to product-related than to process-related risks).

\section{Results of Regression Analysis}

Table 7 depicts the results of regression analyses employing the individual CAR $[-1,0]$ as the dependent variable. As indicated in the last column of Table 7 (i.e., SSR model), we found a significant impact of the predictor, social performance, when a harmful reaction against SSRs arose from salient stakeholders. This evidence thus provides a strong warrant for $\mathrm{H} 3$ (the insurance-like role of social performance). To check multicollinearity, we calculated variance inflation factor (VIF) scores. The highest value of resulting VIF was 1.38, well below the threshold value of 10 . The result was also robust to using alternative CAR measures, such as mean-, market-, and size/value-adjusted models.

Insert Table 7 about here 
Furthermore, as indicated in the first two columns of Table 7, the predictor, social performance, is positively significant only for process-related events. In the case of product risks, the hypothesized predictor is positive but insignificant. This evidence provides only partial support for $\mathrm{H} 4$ (a greater insurance effect for process-related than for product-related risks). This nonfinding is somewhat contrary to expectations. Thus, one may argue that product-related issues can be more closely associated with the product category in the KLD ratings (cf. KLD, 2010). To investigate this issue, we performed the OLS regression again, using product (mean = $-0.16, \mathrm{SD}=0.33$ ) data only. In non-tabulated tests, however, we found that the coefficient of the predictor is still statistically insignificant.

Finally, the problem of self-selection bias may arise, given that the selection of being socially responsible is not a random process. To correct for this possibility, we used the Heckman twostep estimation (Heckman, 1979). We first ran a binary probit model of the likelihood that a firm engages in CSR (i.e., positive versus negative social performance), which generated an estimate for self-selection correction, i.e., the inverse Mills ratio $(\lambda)$. We then added $\lambda$ as a control to the CAR (OLS) regression model for both the positive and negative social performance subsamples. Our non-tabulated test results revealed that the coefficients of the selection bias parameters were insignificant. This evidence suggests that the potential for endogeneity and selection bias is not a concern (Chen et al., 2009).

\section{DISCUSSION}

Quality-related product safety issues have customarily been discussed from a typical risk point of view (e.g., Gray et al., 2011). Those issues are sometimes clearly associated with suppliers' ethical/moral aspects (e.g., intentional acts, see Speier et al., 2011), which are the focus of this study, but neglected from a sustainability perspective. Sweatshop labor within the supply chain is now an emerging topic in the OSCM literature (e.g., Gold et al., 2015); however, only few studies have linked it to supplier sustainability (responsibility) but not from a risk perspective. More importantly, the question remains of how detrimental those issues are to buying firms. 
Under the term of SSRs, this study is the first to estimate the magnitude and severity of its consequences.

Based on a sample of 196 firms' SSRs, we revealed that SSRs are associated with a significant reduction in shareholder value of $1.00 \%$. However, no significant difference in shareholder value losses was found between process-related $(-0.93 \%)$ and product-related risks $(-1.14 \%)$. This evidence has been rarely explored within the SSR literature, and this lack of research is more pronounced when compared to research on SDRs (e.g., Hendricks \& Singhal, 2003, 2005; Kumar, Liu \& Scutella, 2015; Zsidisin, Petkova \& Dam, 2016). By providing rigorous evidence, the results of this study contribute to the ongoing discussion on SSR, an emerging topic where most of the literature is either conceptual or case study-based (e.g., Busse et al., 2016; Foerstl et al., 2010; Giannakis \& Papadopoulos, 2016).

Our empirical result within the supply chain context is in line with those of prior studies in other domains. For example, Bartley and Child (2011) estimated the stock market reaction to antisweatshop campaigns from 1993 to $2000(n=39)$, while Ni et al. (2014) focused on the reactions to private label product recalls from 2000 to $2009(n=164)$. Their examination of US firms found similar shareholder value losses: anti-sweatshop campaigns $\left(\mathrm{CAR}_{[-1,0]}=-1.26 \%\right)$ and product recall events $\left(\mathrm{CAR}_{[-1,0]}=-1.17 \%\right)$. However, both studies were based on different research settings, and more importantly, the results were not derived from an SSR perspective. That said, our findings about process and product events are comparable in magnitude to those of these early studies.

Focusing on SDRs, Hendricks and Singhal (2003) estimated the shareholder value effects of glitches in the supply chain (e.g., delays). Based on a sample of 519 glitches in the US (19892000), they found a significant loss in shareholder wealth, 10.28\%. However, using the same approach, Kumar et al. (2015) found that US firms $(n=313)$ that suffered from disruptions (2003-2012) experience a $0.79 \%$ decrease in shareholder value, which is not as severe as previously found. More recently, Zsidisin et al. (2016) found that such supply chain disruptions (2000-2012) decrease US firms' $(n=116)$ shareholder value by only $1.94 \%$. Indeed, as echoed by Zsidisin et al. (2016, p. 79), “[US] firms may currently be better able to manage and recover 
more quickly from supply chain glitches.” The magnitude of our results is comparable with that of recent SDR studies.

From a sourcing point of view, this study analyzed the insurance-based effect of CSR. This view of CSR has been discussed in strategy research (e.g., Godfrey et al., 2009), but appears to have been neglected in the OSCM literature. In this study, we discussed the benefit of CSR in times of crisis such as SSRs. We then provided evidence on its attenuating effect during the negative event, which is consistent with prior studies (e.g., Flammer, 2013; Koh et al., 2014; Shiu \& Yang, 2017). Focusing on each event type, we found that investors seem to view firms that engage in process risks as a scandal that can be tempered by their moral capital. However, the investors' perception was not found to be significantly affected by the moral capital of firms that engage in product issues, which warrants further discussion. In what follows, we discuss our results from both the theoretical and practical points of view.

\section{Implications for Theory}

The findings of this study confirm the efficient market hypothesis, assuming that stock prices fully reflect all new, publicly available information about SSRs (Fama, 1970). This theory, often used in financial economics (e.g., Deng et al., 2013), has been widely adopted in many other areas of research, including OSCM (e.g., Thirumalai \& Sinha, 2011). However, there are some critics - evidence shows "anomalies," suggesting that this theory may not always be applicable (Mishkin, 2012). Nevertheless, this study provides evidence in favor of market efficiency. Our findings suggest that the market is efficient in the sense that stock prices are adjusted immediately to firms' SSR, a scandalous event that is caused by unsustainable supplier misconduct and thus by harmful reactions from stakeholders whose attributes are salient to the target firms.

Based on data from four vignette-based experiments, Hartmann and Moeller (2014) found what they call "chain liability," stating that even if it occurs outside the firm boundary, a firm may be held accountable for its suppliers' ecologically unsustainable behaviors. From the social sustainability perspective, the results of this study complement their findings, providing 
additional evidence of chain liability. More importantly, our findings extend their study findings by revealing the 'cost' of the liability. As will be discussed later, this study provides empirical evidence of the magnitude of the SSR, answering the question of how detrimental the liability is to buying firms.

Scholars in the field of SDR have proposed its typologies and/or taxonomies (e.g., Harland et al., 2003; Wagner \& Bode, 2008; Zsidisin et al., 2004). In contrast, no study in the SSR literature has investigated this aspect. In fact, SSR has been often discussed from a triple bottom line view (Elkington, 1997), and thus been divided among three pillars: people, planet, and profit (e.g., Giannakis \& Papadopoulos, 2016). Focusing on the people-side of sustainability, we categorized SSR into more specific risk types: process and product. This distinction is based on the typology often applied in prior studies, topics such as environmental initiatives (Gilley et al., 2000) and supplier innovation (Wagner \& Bode, 2014). This study is the first to use the process/product distinction with the view of SSR, thus generating new insights.

Finally, our findings suggest that when facing SSRs, a firm's social performance functions as an insurance mechanism that mitigates the decline in shareholder value. Yet, we found that the reputation insurance only occurs during process-related risks; no insurance-like effects were found for product-related ones. This result is contrary to expectations, leading us to believe that CSR benefit is not always effective (Koh et al., 2014). One possible explanation for this nonfinding is provided by Godfrey (2005, p. 789), who argued that "not even a sterling record of” CSR activity "could dissuade stakeholders from harsh punishments" if firms violate "fundamental ethical obligations and expectations." Unlike SDRs, product-SSRs are events that involve ethical and/or moral questions. The affected stakeholders, especially consumers, may thus perceive these kinds of risk as fundamental violation of their expectations.

Very few prior studies extend the theory of CSR as insurance by analyzing the impact of event characteristics. For example, Godfrey et al. (2009) found that in stakeholder-based scandals, insurance-like effects were greater for firms with CSR engagement than for those without. Product safety issues are such scandals; but, they also include pollution events, which differs from our product-risk classification. From a different perspective, Shiu and Yang (2017) revealed that the impact of CSR as insurance only occurs during initial negative events. Looking 
at our product sample, we still found that the predictor is positive but insignificant, even though we excluded the subsequent coverage (see Table 5). This leads us to re-emphasize the issue of fundamental violation. Overall, this study contributes to research on the breath of its insurance effect, which is only just emerging in the literature.

\section{Implications for Practice}

The findings verify that firms that engage in SSRs are severely punished by the capital market. The $1.00 \%(0.66 \%)$ loss in shareholder wealth associated with SSR events equates to a decline in market value of $\$ 1,042.2$ (\$687.8) million. The shareholder value losses caused by the different types of SSR were also economically significant: \$1,170.8 (median: \$805.7) million for processrelated and \$705.5 (median: \$420.8) million for product-related risks. Despite increased CSR pressures, many of today's products, especially textile goods, are still produced under SSRrelated conditions (Kim et al., 2016). The evidence found in this study offers a relevant reference for managers in buying firms, especially for those considering sourcing from risky suppliers (i.e., low cost but possibly subject to SSR).

In addition, the findings from this study explain why managers in buying firms should pursue social betterment in sourcing operations. Nike’s child labor scandal is an example. In the 1990s, Nike was accused of having sweatshop conditions at its overseas suppliers. The criticism became even worse after the company ignored social activists’ campaigns. Such negative reactions eventually forced Nike to take full responsibility for complying with labor standards in its supply chain (Zadek, 2004). From our viewpoint, Nike would have handled the SSR issue more effectively had it possessed the positive moral capital that can be achieved by building good relations with stakeholders (i.e., high social performance).

For setting priorities, sourcing managers should turn their attention to the types of SSR. As noted, the magnitude of negative impacts caused by both process and product was almost identical. However, the firm's moral capital did mitigate the impact for process risks but not for issues related to product. This means that firms with large amounts of moral capital do not experience as much of a decline in their shareholder value for process-related issues, as do firms 
with less moral capital. In contrast, whether a firm builds positive moral capital or not, product risks cause a significant loss in shareholder value. Thus, at the time of product events, the best way to mitigate their negative impact would be to take responsibility immediately, so that the firm can focus on what it does best. Such an effort could appease stakeholders enough to prevent adverse actions against product-related risks.

It should be noted, however, that such CSR as insurance is limited in its mitigation effects. In other words, firms with reputation insurance could attenuate the consequences of stakeholders' criticism, or SSR; yet, they might be limited in terms of eradicating the criticism beforehand. Recently, there has been a call for research on "true” sustainability (e.g., Pagell \& Shevchenko, 2014; Montabon, Pagell \& Wu, 2016). This view points out that the current OSCM literature has followed what is known as the "utilitarian paradigm" (Matthews et al., 2016), which is concerned with problem mitigation, not problem prevention. In that sense, having CSR as insurance would be enough for "doing good," but not enough for "not doing harm.”

Consequently, sourcing managers need to consider mitigation efforts, and to craft solutions for SSRs. Those solutions should be based on making sourcing practices truly sustainable, and thus of preventing SSRs. Hofmann et al. (2014) present a conceptual framework for this - simply put, managers first need to understand the expectations of salient stakeholders, which are translated into proper criteria on SSRs. Sourcing managers then need to identify, assess, and analyze sources of critical issues based on the criteria (Giannakis \& Papadopoulos, 2016; Hajmohammad \& Vachon, 2016), and this can be done by supplier audits (Chen \& Lee, 2017). For the operations to be truly sustainable, however, firms should do more than monitor their suppliers. That is, firms should not place cost-reduction ahead of selecting suppliers that use unsustainable systems. Further, firms at least need to use collaborative approaches (e.g., joint planning), so that suppliers comply better with the criteria. This would be a way of preventing SSRs, thus shifting into the framework of true sustainability.

\section{CONCLUSION}


This study examines ethical sourcing issues from a risk perspective, often termed SSR, and its economic consequences. Compared to the field of SDR (e.g., Hendricks \& Singhal, 2003, 2005;

Wagner \& Bode, 2008; Zsidisin et al., 2016), empirical research on this topic has been neglected. There is anecdotal evidence on how a SSR damages the buying firm, but we still do not know how much. The dearth of research is surprising given that SSRs now pose a major challenge to global business (Guo et al., 2016). In line with this, we sought to estimate the magnitude and severity of the consequences of SSRs, and to explore the approach to their mitigation. Moreover, we investigated the differential effects of process versus product, both of which are categorized as sub-types of SSR. The results of this study are expected to contribute to the literature and to offer implications for managers in buying firms.

Some limitations of this study should be acknowledged, while opening up future research possibilities. First, this study examined only the immediate stock price impact of SSRs. Although this is in line with market efficiency (Fama, 1970), SSRs that may trigger harmful stakeholder reactions may also distort investors' longer-term perceptions. Thus, future research needs to explore the post-announcement effect of SSRs. Second, these findings are based on a sample of publicly traded US firms. The investor reaction to SSRs may vary in European, Asian or other markets. A replication of this study, particularly across the mentioned markets, would increase the generalizability of our results. Third, our findings suggest that the buffering effect of CSR does not always work. Yet, we failed to delve more into why this is the case, and more importantly, how to eradicate sources of SSR beforehand, something that future studies need to investigate. Finally, the planet-side of sustainability has been extensively covered in the literature. However, little is known about green SSRs, and the damaging effects that buying firms have to bear. Future research should address this under-researched area.

\section{ACKNOWLEDGMENTS}

We thank the editors, associated editor, and three anonymous reviewers for their constructive comments and suggestions. We also thank Brian W. Jacobs and Riccardo Mogre for their helpful feedback on an early version of this manuscript. Finally, we thank M. Ramkumar, David B. 
Grant, Kiran Fernandes, David A. Menachof, and participants in conference sessions at the annual meetings of POMS, ELA and EurOMA for their useful discussion.

\section{REFERENCES}

Argenti, P.A. (2004). Collaborating with activists: How Starbucks works with NGOs. California Management Review, 47, 91-116.

Barnett, M.L. (2007). Stakeholder influence capacity and the variability of financial returns to corporate social responsibility. Academy of Management Review, 32, 794-816.

Barnett, M.L. (2014). Why stakeholders ignore firm misconduct: A cognitive view. Journal of Management, 40, 676-702.

Bartley, T., \& Child, C. (2011). Movements, markets and fields: The effects of anti-sweatshop campaigns on U.S. firms, 1993-2000. Social Forces, 90, 425-451.

Brown, S.J., \& Warner, J.B. (1985). Using daily stock returns: The case of event studies. Journal of Financial Economics, 14, 3-31.

Busse, C., Kach, A.P., \& Bode, C. (2016). Sustainability and the false sense of legitimacy: How institutional distance augments risk in global supply chains. Journal of Business Logistics, 37, 312-328.

Casey, N. (2007). Mattel toys to be pulled amid lead fears. The Wall Street Journal, August 2, A3.

Chan, J. (2013). A suicide survivor: The life of a Chinese worker. New Technology, Work and Employment, 28, 84-99.

Chen, C.M., \& Delmas, M. (2011). Measuring corporate social performance: An efficiency perspective. Production and Operations Management, 20, 789-804.

Chen, L., \& Lee, H.L. (2017). Sourcing under supplier responsibility risk: The effects of certification, audit, and contingency payment. Management Science, 63, 2795-2812.

Chen, Y. B., Ganesan, S., \& Liu, Y. (2009). Does a firm's product-recall strategy affect its financial value? An examination of strategic alternatives during product-harm crises. Journal of Marketing, 73, 214-226.

Cordeiro, J.J., \& Tewari, M. (2015). Firm characteristics, industry context, investor reactions to environmental CSR: A stakeholder theory approach. Journal of Business Ethics, 130, 833-849.

Deng, X., Kang, J., \& Low, B.S. (2013). Corporate social responsibility and stakeholder value maximization: Evidence from mergers. Journal of Financial Economics, 110, 87-109.

Dorobantu, S., Henisz, W.J., \& Nartey, L. (2017). Not all sparks light a fire: Stakeholder and shareholder reactions to critical events in contested markets. Administrative Science Quarterly, 62, 561-597.

Elkington, J. (1997). Cannibals with Forks: The Triple Bottom Line of 21st Century. Capstone Publishing Ltd.

Fama, E. F. \& French, K. R. (1993), Common risk-factors in the returns on stocks and bonds. Journal of Financial Economics, 33, 3-56.

Fama, E.F. (1970). Efficient capital markets: A review of theory and empirical work. Journal of Finance, 25, 383-417.

Flammer, C. (2013). Corporate social responsibility and shareholder reaction: The environmental awareness of investors. Academy of Management Journal, 56, 758-781.

Foerstl, K., Reuter, C., Hartmann, E., \& Blome, C. (2010). Managing supplier sustainability risks in a dynamically changing environment - Sustainable supplier management in the chemical industry. Journal of Purchasing \& Supply Management, 16, 118-130.

Freeman, R.E., Harrison, J.S., Wicks, A.C., Parmar, B., \& de Colle, S. (2010). Stakeholder Theory: The State of the Art. Cambridge University Press.

Frooman, J. (1999). Stakeholder influence strategies. Academy of Management Review, 24, 191-205.

Giannakis, M., \& Papadopoulos, T. (2016). Supply chain sustainability: A risk management approach. International Journal of Production Economics, 171, 455-470. 
Gilley, K.M., Worrell, D.L., Davidson, W.N., \& El-Jelly, A. (2000). Corporate environmental initiatives and anticipated firm performance: The differential effects of process-driven versus product-driven greening initiatives. Journal of Management, 26, 1199-1216.

Godfrey, P.C. (2005). The relationship between corporate philanthropy and shareholder wealth: A risk management perspective. Academy of Management Review, 30, 777-798.

Godfrey, P.C., Merrill, C.B., \& Hansen, J.M. (2009). The relationship between corporate social responsibility and shareholder value: An empirical test of the risk management hypothesis. Strategic Management Journal, 30, 425-445.

Gold, S., Trautrims, A., \& Trodd, Z. (2015). Modern slavery challenges to supply chain management. Supply Chain Management: An International Journal, 20, 485-494.

Gray, J. V., Roth, A. V., \& Leiblein, M. J. (2011). Quality risk in offshore manufacturing: Evidence from the pharmaceutical industry. Journal of Operations Management, 29, 737-752.

Guo, R., Lee, H.L., \& Swinney, R. (2016). Responsible sourcing in supply chains. Management Science, 62, 2722-2744.

Hajmohammad, S., \& Vachon, S. (2016). Mitigation, avoidance, or acceptance? Managing supplier sustainability risk. Journal of Supply Chain Management, 52, 48-65.

Harland, C., Brenchley, R., \& Walker, H. (2003). Risk in supply networks. Journal of Purchasing \& Supply Management, 9, 51-62.

Hartmann, J., \& Moeller, S. (2014). Chain liability in multitier supply chains? Responsibility attributions for unsustainable supplier behavior. Journal of Operations Management, 32, 281-294.

Heckman, J. J. (1979). Sample selection bias as a specification error. Econometrica, 47, 153-161.

Hendricks, K.B., \& Singhal, V.R. (2003). The effect of supply chain glitches on shareholder wealth. Journal of Operations Management, 21, 501-522.

Hendricks, K.B., \& Singhal, V.R. (2005). Association between supply chain glitches and operating performance. Management Science, 51, 695-711.

Hodge, K. (2013). Horsemeat scandal: Tesco drops burger meat supplier after 'breach of trust'. Independent, 30 January.

Hofmann, H., Busse, C., Bode, C., \& Henke, M. (2014). Sustainability-related supply chain risks: Conceptualization and management. Business Strategy and the Environment, 23, 160-172.

Hora, M., Bapuji, H., \& Roth, A.V. (2011). Safety hazard and time to recall: The role of recall strategy, product defect type, and supply chain player in the US toy industry. Journal of Operations Management, 29, 766-777.

Jacobs, B., \& Singhal, V.R. (2017). The effect of the Rana Plaza disaster on shareholder wealth of retailers: Implications for sourcing strategies and supply chain governance. Journal of Operations Management, 4951, 52-66.

Kach, A., Busse, C., Azadegan, A., \& Wagner, S.M. (2016). Maneuvering through hostile environments: How firms leverage product and process innovativeness. Decision Sciences, 47, 907-956.

Kim, S., Colicchia, C., \& Menachof, D. (2016). Ethical sourcing: An analysis of the literature and implications for future research. Journal of Business Ethics, DOI: https://doi.org/10.1007/s10551-016-3266-8.

Kim, S., \& Lee, S.Y. (2012). Stakeholder pressure and the adoption of environmental logistics practices: Is eco-oriented culture a missing link?. International Journal of Logistics Management, 23, 238-258.

King, B. G., \& Soule, S. A. (2007). Social movements as extra-institutional entrepreneurs: The effect of protests on stock price returns. Administrative Science Quarterly, 52, 413-442.

Klassen, R.D., \& Vereecke, A. (2012). Social issues in supply chains: Capabilities link responsibility, risk (opportunity), and performance. International Journal of Production Economics, 140, 103-115.

KLD, (2010). Getting started with KLD stats and KLD's ratings definitions. Available at: http://cdnete.lib.ncku.edu.tw/93cdnet/english/lib/Getting_Started_With_KLD_STATS.pdf.

Kleindorfer, P.R., \& Saad, G.H. (2005). Managing disruption risks in supply chains. Production and Operations Management, 14, 53-68.

Koh, P.S., Qian, C., \& Wang, H. (2014). Firm litigation risk and the insurance value of corporate social performance. Strategic Management Journal, 35, 1464-1482. 
Kumar, S., Liu, J., \& Scutella, J. (2015). The impact of supply chain disruptions on stockholder wealth in India. International Journal of Physical Distribution \& Logistics Management, 45, 938-958.

Lo, C. K. Y., Pagell, M., Fan, D., Wiengarten, F., \& Yeung, A. C. L. (2014). OHSAS 18001 certification and operating performance: The role of complexity and coupling. Journal of Operations Management, 32, 268-280.

MacKinlay, A.C. (1997). Event studies in economics and finance. Journal of Economic Literature, 35, 13-39.

Marucheck, A., Greis, N., Mena, C., \& Cai, L. N. (2011). Product safety and security in the global supply chain: Issues, challenges and research opportunities. Journal of Operations Management, 29, 707-720.

Matthews, L., Power, D., Touboulic, A., \& Marques, L. (2016). Building bridges: Toward alternative theory of sustainable supply chain management. Journal of Supply Chain Management, 52, 82-94.

McQueen, M.P. (2007). Retailers face the test of testing: Closer oversight of toys is designed to head off costly suits, new laws. The Wall Street Journal, November 26, A6.

McWilliams, A., \& Siegel, D. (1997). Event studies in management research: Theoretical and empirical issues. Academy of Management Journal, 40, 626-657.

Minor, D., \& Morgan, J. (2011). CSR as reputation insurance: Primum non Nocere. California Management Review, 53, 40-59.

Mishkin, F.S. (2012). The Economics of Money, Banking and Financial Markets (Business School 3rd edition). Pearson.

Mitchell, R.K., Agle, B.R., \& Wood, D.J. (1997). Toward a theory of stakeholder identification and salience: Defining the principle of who and what really counts. Academy of Management Review, 22, 853-886.

Montabon, F., Pagell, M., \& Wu, Z. (2016). Making sustainability sustainable. Journal of Supply Chain Management, 52, 11-27

Murphy, C. (2012). KFC feels heat in China: TV report on suppliers improperly using antibiotics complicates sales decline. The Wall Street Journal, December 20, B7.

New, S. J. (2015). Modern slavery and the supply chain: The limits of corporate social responsibility? Supply Chain Management: An International Journal, 20, 697-707.

Ni, J., Flynn, B.B., \& Jacobs, F.R. (2014). Impact of product recall announcement on retailers' financial value. International Journal of Production Economics, 153, 309-322.

Pagell, M., \& Shevchenko, A. (2014). Why research in sustainable supply chain management should have no future. Journal of Supply Chain Management, 50, 44-55.

Pagell, M., Veltri, A., \& Johnston, D. (2016). Getting workplace safety right. MIT Sloan Management Review, $57,11-15$.

Peloza, J. (2006). Using corporate social responsibility as insurance for financial performance. California Management Review, 48, 52-72.

Reuter, C., Foerstl, K., Hartmann, E., \& Blome, C. (2010). Sustainable global supplier management: The role of dynamic capabilities in achieving competitive advantage. Journal of Supply Chain Management, 46, 45-63.

Roehrich, J.K., Grosvold, J., \& Hoejmose, S.U. (2014). Reputational risks and sustainable supply chain management: Decision making under bounded rationality. International Journal of Operations \& Production Management, 34, 695-719.

Roth, A.V., Tsay, A.A., Pullman, M.E., \& Gray, J.V. (2010). Unraveling the food supply chain: Strategic insights from China and the 2007 recalls. Journal of Supply Chain Management, 44, 22-39.

Shafiq, A., Klassen, R.D., Johnson, P.F., \& Awaysheh, A. (2014). Socially responsible practices: An exploratory study on scale development using stakeholder theory. Decision Sciences, 45, 683-716.

Sherr, I. (2011). Apple says China partner made changes for workers. The Wall Street Journal, February 15, B5.

Shiu, Y.M., \& Yang, S.L. (2017). Does engagement in corporate social responsibility provide strategic insurance-like effects? Strategic Management Journal, 38, 455-470.

Speier, C., Whipple, J. M., Closs, D. J., \& Voss, M. D. (2011). Global supply chain design considerations: Mitigating product safety and security risks. Journal of Operations Management, 29, 721-736.

Steven, A. B., Dong, Y., \& Corsi, T. (2014). Global sourcing and quality recalls: An empirical study of outsourcing-supplier concentration-product recalls linkages. Journal of Operations Management, 32, 241- 
253.

Thirumalai, S., \& Sinha, K. K. (2011). Product recalls in the medical device industry: An empirical exploration of the sources and financial consequences. Management Science, 57, 376-392.

Wagner, S.M., \& Bode, C. (2008). An empirical examination of supply chain performance along several dimensions of risk. Journal of Business Logistics, 29, 307-325.

Wagner, S.M., \& Bode, C. (2014). Supplier relationship-specific investments and the role of safeguards for supplier innovation sharing. Journal of Operations Management, 32, 65-78.

Wowak, K. D., \& Boone, C. A. (2015). So many recalls, so little research: A review of the literature and road map for future research. Journal of Supply Chain Management, 51, 54-72.

Zadek, S. (2004). The path to corporate responsibility. Harvard Business Review, 82, 125-132.

Zhao, X. D., Li, Y. N., \& Flynn, B. B. (2013). The financial impact of product recall announcements in China. International Journal of Production Economics, 142, 115-123.

Ziobro, P. (2010). McDonald's recalls glasses used in 'Shrek’ promotion: Presence of cadmium prompts voluntary repurchase of 12 million collectibles. The Wall Street Journal, June 5, B5.

Zsidisin, G.A., Ellram, L.M., Carter, J.R., \& Cavinato, J.L. (2004). An analysis of supply risk assessment techniques. International Journal of Physical Distribution \& Logistics Management, 34, 397-413.

Zsidisin, G.A., Petkova, B.N., \& Dam, L. (2016). Examining the influence of supply chain glitches on shareholder wealth: Does the reason matter? International Journal of Production Research, 54, 69-82. 


\section{TABLE 1}

\section{Type of SSR and Some Examples}

\begin{tabular}{|c|c|c|c|}
\hline SSR category & Definition & Issues & Examples (reference) \\
\hline $\begin{array}{l}\text { Process-related } \\
\text { risks }\end{array}$ & $\begin{array}{l}\text { refer to suppliers' } \\
\text { ethical/moral } \\
\text { misconduct that is } \\
\text { associated with } \\
\text { process violations }\end{array}$ & $\begin{array}{l}\text { Sweatshop, forced } \\
\text { and child labor, } \\
\text { unfair wages, } \\
\text { occupational health } \\
\text { and safety, etc. }\end{array}$ & $\begin{array}{l}\text { Nike’s child labor (Zadek, } \\
\text { 2004), Apple-Foxconn's } \\
\text { employee suicide (Chan, 2013), } \\
\text { Starbucks' unfair trade (Argenti, } \\
\text { 2004), Rana Plaza collapse } \\
\text { (Jacobs \& Singhal, 2017), }\end{array}$ \\
\hline $\begin{array}{l}\text { Product-related } \\
\text { risks }\end{array}$ & $\begin{array}{l}\text { reflect suppliers' } \\
\text { ethical/moral } \\
\text { misconduct that is } \\
\text { associated with } \\
\text { product violations }\end{array}$ & $\begin{array}{l}\text { Product quality and } \\
\text { safety hazards (e.g., } \\
\text { tainted toys), food- } \\
\text { harm crises (e.g., } \\
\text { horsemeat), etc. }\end{array}$ & $\begin{array}{l}\text { Mattel's lead-tainted toy (Casey, } \\
\text { 2007), McDonald's cadmium- } \\
\text { laced glasses (Ziobro, 2010), } \\
\text { Horsemeat scandal (Hodge, } \\
\text { 2013), Yum’s antibiotics in } \\
\text { chickens (Murphy, 2012) }\end{array}$ \\
\hline
\end{tabular}


TABLE 2

Sample Distribution

\begin{tabular}{llll}
\hline & Process & Product & SSR \\
\hline Time trend (year range) & & & \\
Early (1985-1994) & 15 & 3 & 18 \\
Middle (1995-2004) & 22 & 12 & 34 \\
Recent (2005-2014) & 92 & 53 & 144 \\
Industry (2-digit SIC range) & & & \\
$\quad$ Mining \& construction (10-17) & 6 & 1 & 7 \\
Manufacturing (20-39) & 88 & 37 & 125 \\
Transportation \& public utilities (40-49) & 2 & 1 & 3 \\
Wholesale \& retail trade (50-59) & 32 & 28 & 60 \\
Services (60-89) & 1 & & 1 \\
Total & 129 & 67 & 196 \\
\hline
\end{tabular}


TABLE 3

Descriptive Statistics and Correlation Matrix

\begin{tabular}{lcllrrrrr}
\hline Variable & Mean & SD & 1 & 2 & 3 & 4 & 5 & 6 \\
\hline 1. CAR [-1, 0] & -0.01 & 0.02 & & & & & & \\
2. Social performance & 0.45 & 0.98 & .28 & & & & & \\
3. Firm size & 10.26 & 1.41 & .23 & .25 & & & & \\
4. Time trend & 2007.19 & 5.37 & .13 & .30 & .35 & & & \\
5. Fatality & 0.17 & 0.37 & .01 & .23 & .19 & .32 & & \\
6. Legal action & 0.11 & 0.32 & .20 & -.14 & -.01 & -.14 & -.02 & \\
7. Emerging country & 0.60 & 0.49 & .02 & .17 & .04 & .26 & .23 & -.17 \\
\hline
\end{tabular}

Notes: $n=126$. Coefficient values more than 0.20 are statistically significant at $p<0.05$. 
TABLE 4

CAR for SSRs

\begin{tabular}{lclllll}
\hline Event day(s) & \multicolumn{2}{c}{ Mean (\%) } & \multicolumn{2}{c}{ Median (\%) } & \multicolumn{2}{c}{ \% Negative } \\
\hline-5 & -0.02 & $(-0.23)$ & 0.03 & $(0.09)$ & 48.47 & $(0.66)$ \\
-4 & $-0.25^{*}$ & $(-2.07)$ & -0.14 & $(-1.60)$ & 53.06 & $(-0.61)$ \\
-3 & -0.02 & $(-0.19)$ & -0.05 & $(-0.56)$ & 52.55 & $(-0.47)$ \\
-2 & $0.33^{* *}$ & $(2.85)$ & $0.23^{*}$ & $(2.53)$ & $42.86^{*}$ & $(2.24)$ \\
-1 & $-0.73^{* * *}$ & $(-7.34)$ & $-0.48^{* * *}$ & $(-6.61)$ & $68.88^{* * *}$ & $(-5.05)$ \\
0 & $-0.27^{* *}$ & $(-2.68)$ & -0.06 & $(-1.58)$ & 50.51 & $(0.10)$ \\
1 & 0.05 & $(0.45)$ & 0.11 & $(0.54)$ & 46.94 & $(1.09)$ \\
2 & -0.11 & $(-1.22)$ & -0.09 & $(-1.07)$ & 52.55 & $(-0.47)$ \\
3 & -0.19 & $(-1.35)$ & -0.16 & $(-1.50)$ & 55.61 & $(-1.33)$ \\
4 & -0.17 & $(-1.29)$ & 0.00 & $(-0.89)$ & 50.00 & $(0.24)$ \\
5 & 0.18 & $(1.28)$ & 0.11 & $(1.53)$ & 45.41 & $(1.52)$ \\
{$[-5,-2]$} & 0.04 & $(0.18)$ & 0.01 & $(0.36)$ & 49.49 & $(0.38)$ \\
{$[-1,0]$} & $-1.00^{* * *}$ & $(-7.49)$ & $-0.66^{* * *}$ & $(-6.30)$ & $63.78^{* * *}$ & $(-3.61)$ \\
{$[1,5]$} & -0.24 & $(-0.92)$ & 0.10 & $(-0.36)$ & 48.98 & $(0.52)$ \\
\hline
\end{tabular}

Notes: $n=196$. $t$-statistics for means, Wilcoxon signed-rank Z-statistics for medians, and generalized sign Zstatistics for \% Negatives are shown in parentheses. ${ }^{*} p<0.05 ;{ }^{* *} p<0.01 ;{ }^{* * *} p<0.001$. 
TABLE 5

Robustness Checks for CAR $[-1,0]$

\begin{tabular}{llllllll}
\hline Variable estimated & $n$ & \multicolumn{2}{c}{ Mean (\%) } & \multicolumn{2}{c}{ Median $(\%)$} & \multicolumn{2}{c}{$\%$ Negative } \\
\hline Collective events & 143 & $-1.25^{* * *}$ & $(-7.95)$ & $-0.84^{* * *}$ & $(-6.63)$ & $68.53^{* * *}$ & $(-4.25)$ \\
Abnormal samples & 153 & $-1.03^{* * *}$ & $(-6.53)$ & $-0.68^{* * *}$ & $(-5.47)$ & $62.75^{* *}$ & $(-2.85)$ \\
Subsequent coverage & 130 & $-1.10^{* * *}$ & $(-6.34)$ & $-0.80^{* * *}$ & $(-5.35)$ & $63.08^{* *}$ & $(-2.73)$ \\
Overlapping cases & 186 & $-0.99^{* * *}$ & $(-7.23)$ & $-0.68^{* * *}$ & $(-6.18)$ & $64.52^{* * *}$ & $(-3.74)$ \\
Mean-adjusted & 196 & $-1.07^{* * *}$ & $(-6.39)$ & $-0.69^{* * *}$ & $(-5.52)$ & $63.27^{* * *}$ & $(-3.63)$ \\
Market-adjusted & 196 & $-0.93^{* * *}$ & $(-7.24)$ & $-0.63^{* * *}$ & $(-6.27)$ & $63.27^{* * *}$ & $(-3.73)$ \\
Size/value-adjusted & 196 & $-0.91^{* * *}$ & $(-6.83)$ & $-0.53^{* * *}$ & $(-5.68)$ & $63.78^{* * *}$ & $(-3.59)$ \\
\hline
\end{tabular}

Note: $t$-statistics for means, Wilcoxon signed-rank Z-statistics for medians, and generalized sign $Z$-statistics for \% Negatives are shown in parentheses.

${ }^{* *} p<0.01 ;{ }^{* * *} p<0.001$. 
TABLE 6

CAR [-1, 0] for SSR Event-type and its Differential Effects

\begin{tabular}{llllllll}
\hline Event-type & $n$ & \multicolumn{2}{c}{ Mean (\%) } & \multicolumn{2}{c}{ Median (\%) } & \multicolumn{2}{c}{$\%$ Negative } \\
\hline Process-related & 129 & $-0.93^{* * *}$ & $(-5.89)$ & $-0.64^{* * *}$ & $(-5.09)$ & $65.89^{* * *}$ & $(-3.44)$ \\
Product-related & 67 & $-1.14^{* * *}$ & $(-4.60)$ & $-0.68^{* * *}$ & $(-3.66)$ & 59.70 & $(-1.40)$ \\
Difference & & -0.21 & $(-0.76)$ & -0.04 & $(-0.30)$ & & \\
\hline
\end{tabular}

Notes: $t$-statistics for means and its comparison, Wilcoxon signed-rank Z-statistics for medians, Mann-Whitney Zstatistics for median comparison, and generalized sign $Z$-statistics for $\%$ negatives are shown in parentheses. ${ }^{* * *} p<0.001$. 
TABLE 7

Regression Estimation of CAR $[-1,0]$

\begin{tabular}{|c|c|c|c|}
\hline Variable & Type: Process & Type: Product & Overall: SSR \\
\hline Constant & $\begin{array}{l}-0.737 \\
(-0.814)\end{array}$ & $\begin{array}{l}-0.952 \\
(-0.739)\end{array}$ & $\begin{array}{l}-0.490 \\
(-0.692)\end{array}$ \\
\hline Social performance & $\begin{array}{l}0.327^{*} \\
(2.495)\end{array}$ & $\begin{array}{l}0.132 \\
(0.921)\end{array}$ & $\begin{array}{l}0.245^{*} \\
(2.586)\end{array}$ \\
\hline \multicolumn{4}{|l|}{ Industry-level controls } \\
\hline Mining \& construction ${ }^{\mathrm{a}}$ & & $\begin{array}{l}-0.104 \\
(-0.741)\end{array}$ & $\begin{array}{l}-0.083 \\
(-0.971)\end{array}$ \\
\hline Transportation \& public utilities ${ }^{a}$ & $\begin{array}{l}0.030 \\
(0.243)\end{array}$ & $\begin{array}{l}0.155 \\
(1.088)\end{array}$ & $\begin{array}{l}0.098 \\
(1.105)\end{array}$ \\
\hline Wholesale \& retail ${ }^{\mathrm{a}}$ & $\begin{array}{l}-0.010 \\
(-0.079)\end{array}$ & $\begin{array}{l}-0.095 \\
(-0.608)\end{array}$ & $\begin{array}{l}0.010 \\
(0.117)\end{array}$ \\
\hline Services $^{\mathrm{a}}$ & $\begin{array}{l}0.112 \\
(0.994)\end{array}$ & & $\begin{array}{l}0.086 \\
(1.004)\end{array}$ \\
\hline \multicolumn{4}{|l|}{ Firm-level controls } \\
\hline Firm size & $\begin{array}{l}0.028 \\
(0.223)\end{array}$ & $\begin{array}{l}0.224 \\
(1.426)\end{array}$ & $\begin{array}{l}0.144 \\
(1.567)\end{array}$ \\
\hline \multicolumn{4}{|l|}{ Event-level controls } \\
\hline Time trend & $\begin{array}{l}0.109 \\
(0.784)\end{array}$ & $\begin{array}{l}0.102 \\
(0.699)\end{array}$ & $\begin{array}{l}0.063 \\
(0.641)\end{array}$ \\
\hline Fatality & $\begin{array}{l}-0.139 \\
(-1.169)\end{array}$ & $\begin{array}{l}0.047 \\
(0.307)\end{array}$ & $\begin{array}{l}-0.099 \\
(-1.082)\end{array}$ \\
\hline Legal action & $\begin{array}{l}0.256^{*} \\
(2.216)\end{array}$ & $\begin{array}{l}0.208 \\
(1.310)\end{array}$ & $\begin{array}{l}0.248^{* *} \\
(2.848)\end{array}$ \\
\hline Emerging country & $\begin{array}{l}0.163 \\
(1.343)\end{array}$ & $\begin{array}{l}-0.189 \\
(-1.118)\end{array}$ & $\begin{array}{l}-0.002 \\
(-0.019)\end{array}$ \\
\hline Observations & 74 & 52 & 126 \\
\hline$F$ for the model & $2.052^{*}$ & 1.609 & $2.753^{* *}$ \\
\hline$R^{2}(\%)$ & 22.40 & 25.64 & 19.32 \\
\hline Adjusted $R^{2}(\%)$ & 11.48 & 9.71 & 12.30 \\
\hline
\end{tabular}

Note: Main table contains standardized coefficients; $t$-Statistics are shown in parentheses; ${ }^{a}$ referent category is manufacturing.

${ }^{*} p<0.05 ;{ }^{* *} p<0.01$. 